\title{
THE EFFECT OF BLANCHING TEMPERATURE ON THE TEXTURE OF LACTIC FERMENTED CUCUMBERS (Cucumis sativus L.)
}

\author{
Tincuța-Marta Gocan ${ }^{1}$, Ileana Andreica ${ }^{1}$, Gheorghe Poșta ${ }^{2}$, Dănuț-Nicolae Măniuțiu ${ }^{1}$, \\ Sándor Rózsa ${ }^{1 *}$, Emese Egyed ${ }^{1}$ \\ ${ }^{1}$ University of Agricultural Sciences and Veterinary Medicine, \\ Faculty of Horticulture, 400372, 3-5 Mănăştur Street, Cluj-Napoca, Romania \\ ${ }^{2}$ Banat University of Agricultural Sciences and Veterinary Medicine „King Michael I of Romania" from Timisoara, \\ Faculty of Horticulture and Forestry, 119 Aradului Street, 300645 Timisoara, Romania
}

\begin{abstract}
In the history of mankind, the use of canned vegetables has been a source of ensuring a diverse range of vegetables in winter and has led to the development of cropping systems with technological features specific to industrialization. The effects of blanching temperature on the texture and quality of cucumber fruits under the conditions of lactic fermentation have been important topics of study over time. In comparison, in this paper we studied the complex influence of fermentation time (25 days) and temperature level $\left(22^{\circ} \mathrm{C}\right)$ on qualitative aspects such as pH level, total acidity and salt concentration change. Two different temperatures were also used for blanching with the salt solutions, $96{ }^{\circ} \mathrm{C}$ and $67^{\circ} \mathrm{C}$. The results of this study show that iodized sea salt was useful for whole pickles because they showed a better taste and texture. Pickled cucumbers blanched at $96{ }^{\circ} \mathrm{C}$ showed a better texture and lower acidity than those at $67{ }^{\circ} \mathrm{C}$.
\end{abstract}

Keywords: cucumbers, fermentation, vegetables, blanching, salt.

\section{INTRODUCTION}

Fermentation is a food biotechnological process used worldwide and is a process that falls within biosecurity standards. Lactic acid fermentation is one of the oldest methods used worldwide for preserving vegetables and fruits (Alfredo et al., 1997). The manufacture of fermented foods with lactic acid bacteria (LAB) has ancient and extensive traditions on the two continents, Europe and Asia. The pyramidal basis for the production of traditional fermented foods is in the household, where an enormous number of microbial inoculants and raw materials are used in a random way (Ashaolu, 2020).

The low cost of fermentation and LAB crops have made it easier to ferment many substrates from vegetables, fruits and use certain parts of plants to sensory properties of food and reduce toxic elements (Simatende et al., 2015). Whether in a solid or submerged state, fermentation, by acidification, leads to the production of health-promoting foods with desired qualities, such as shelf life, texture, taste, aroma and color (by Roos and de Vuyst, 2018).

$\mathrm{LAB}$ fermentation allows the preservation of many vegetables, as well as the transformation of the raw material into a new product with unique sensory properties, flavors, better textures and 
increased nutritional value. During fermentation, the raw substrates become colonized by native microorganisms that use their enzymes to digest food components into end products acceptable to potential consumers (Ashaolu, 2020; Ray and Sivakumar, 2009).

A study by Maki shows that in Europe, a total of 21 vegetables are processed by fermentation, in addition to an unspecified number of mixtures of vegetables and juices (Mäki, 2004).

Most traditional preparation and fermentation processes are kept secret and are passed down from generation to generation, while many of them are performed on a household, family system scale, using back slopping (Tamang et al., 2015). Different types of vegetables are fermented, mainly by mixing with salt for a few hours and then adding to the water on the rice, bread (to speed up the fermentation time and get an attractive color), to be eaten in the first three days (Ly et al., 2018).

If pickled, it is not necessary to dry; rather, the sinki is mixed with spices and bottled. It appears that Tamang et al. (1993) found numerous strains of Lactobacillus plantarum, L. brevis and $L$. fermentum as LAB predominant in fermentation.

The processing and marketing of fermented cucumbers is carried out both in Europe and in Asia. They are made into a product with different names and names "jioang-gua" in Taiwan, "khalpi" in Nepal and India, "paocai" in China, "oiji" in Korea or "pickles" in many parts of the United States, Europe (Romania, Russia, Ukraine) and Canada (Franco et al., 2016). Most cucumbers are fermented in a salt solution. Cucumber fermentation is based on the presence of natural LAB or, in some cases, inoculum from a pure starting culture (Fleming et al. 1988).

Preservation by lactic fermentation helps prevent diseases such as diarrhea and cirrhosis, while antioxidants in fermented vegetables can help eradicate harmful free radicals that act in the development of degenerative diseases (Swain et al., 2014; Sanlier et al., 2017).

Cucumber (Cucumis sativus L.) belongs to the Cucurbitaceae family and is native to South Asia (Adams et al., 1992), being widely cultivated throughout the tropics and subtropical region of the world. The nutritional value of cucumber fruits is given by their content in salts of calcium, iron, magnesium, phosphorus, potassium, zinc, $\mathrm{B}_{1}, \mathrm{~B}_{2}, \mathrm{~B}_{3}, \mathrm{~B}_{5}, \mathrm{~B}_{6}$ vitamins, folic acid, vitamin $\mathrm{C}$ (Hoza, 2013). Cucumber is a truly versatile vegetable due to its diversified range of uses in the form of salads, pickles and beauty products (More, 2015).

In this paper we studied the complex influence of fermentation time ( 25 days) and temperature level $\left(22^{\circ} \mathrm{C}\right)$ on qualitative aspects such as $\mathrm{pH}$ level, total acidity and salt concentration change.

\section{MATERIALS AND METHODS}

The cultivation of cucumbers necessary for qualitative laboratory determinations was carried out in a household type solarium with a width of $5.4 \mathrm{~m}$ and an area of $135 \mathrm{~m}^{2}$, in the Aghireșu-Fabrici, Cluj County vegetable farm.

The biological material used in the experiment was represented by the Ekol F1 (Syngenta®) hybrid of cornichon cucumbers. The parthenocarpic hybrid is intended for cycle I and II crops in a protected system. The plants are vigorous and form 3-5 fruits at the level of each node, but they do not have the phenomenon of emitting lateral shoots, which does not amplify the production cost with special pinching works. The fruits are uniform, dark green, with spikes, with a very pleasant commercial appearance. This pickle hybrid has a high tolerance to high summer temperatures and pathogens such as Cladosporium cucumerinum, Sphaerotheca fulginea and Cucumber mosaic virus. The production of biological material for the establishment of experimental culture was carried out in family-type heated solariums, by sowing directly in pots with a nutritious substrate and a diameter of $9 \mathrm{~cm}$. The age of the seedling at planting was 30 days, and the planting took place in the 
last decade of April in equidistant rows at a distance of $75 \mathrm{~cm}$ between rows, respectively $35-40 \mathrm{~cm}$ between plants per row.

For pickling, we mainly use quality cucumbers with fruit II (irregular shape, larger diameter, or deformed. For pickling, brine is used, in combination with various aromatic and decorative species (thyme, dill, carrot). The sea salt used for brine has the following composition: $98 \%$ sodium concentration, potassium iodide $32.5 \mathrm{mg} \mathrm{kg}^{-1}$. The pickling process reduces the vitamin content of vegetables, but keeps them in high values other preservation processes (e.g. boiling), and in addition, preserve them for longer.

The lactic fermentation process takes place in three phases:

- phase I or preliminary phase in which the heterofermentative lactic acid bacteria act, producing lactic acid and other substances, especially in gaseous form $\left(\mathrm{CO}_{2}, \mathrm{H}_{2}\right)$. The anaerobic environment that is created in this phase is characterized by massive releases of $\mathrm{CO}_{2}$, is turbulent and agitated. This phase lasts 2-4 days if the fermentation takes place at a temperature of $20-25{ }^{\circ} \mathrm{C}$;

- phase II or main phase lasts 3-4 weeks, the fermentation process is continued by homofermentative bacteria that produce only lactic acid and small amounts of $\mathrm{CO}_{2}$. At the end of this phase the $\mathrm{pH}$ of the medium reaches 3.8-4.0, and the total acidity at the concentration of $2 \%$;

- phase III or secondary phase in which the fermentation of residual sugars takes place under the action of fermentative yeasts, provided that the development of lactic acid bacteria is inhibited by the low $\mathrm{pH}$ level. At the end of this phase the concentration of lactic acid reaches to $2.5 \%$.

The factors that influence lactic fermentation are:

- the concentration of brine (3-6\%) has a selective role on lactic microorganisms, prevents the softening of products and extracts by diffusion fermentable sugars;

- the fermentation temperature between $15-25^{\circ} \mathrm{C}$, must be higher in the first phase $\left(25^{\circ} \mathrm{C}\right)$ to start the process then reduce to form the flavor.

Sliced cucumbers (CF) and whole cucumbers (CI), blanched at $67{ }^{\circ} \mathrm{C}$ and $96{ }^{\circ} \mathrm{C}$, were used in the experiments.

Determination of sodium chloride was performed by the Mohr (argentometric) method.

The $\mathrm{pH}$ was determined as follows: pickled cucumber fruit was cut into 3 pieces, and the middle piece was ground with a sprayer (WHF-714, Won-Jin) and centrifuged at $15000 \times \mathrm{g}$ for $20 \mathrm{~min}$., after which the $\mathrm{pH}$ level was measured with a $\mathrm{pH}$ meter (DP-215M, Dongwoo Medical, Korea).

The titratable acidity was determined by titration with $0.1 \mathrm{~N} \mathrm{NaOH}$ to $\mathrm{pH} 7.0 \pm 0.05$ (Alfredo et al. 1997) and calculated as a percentage of lactic acid (Fleming et al. 1988).

\section{RESULTS AND DISCUSSIONS}

From the analysis of the experimental results on the $\mathrm{pH}$ changes of pickled cucumber fruits during lactic fermentation within 25 days (Table 1), it can be seen that all samples showed a similar tendency to change this characteristic, with reduced differences shown in Figure 1. In the initial stage of fermentation, the $\mathrm{pH}$ values decreased slowly, as after 10 days a lot and return at a reduced rate again in the subsequent stage of the fermentation process. It seems that there may be a very active fermentation initially and acid formed could reduce the microbial action in the latter part of the fermentation (Alfredo et al, 1997). Samples with prepared salt solutions preheated to $96^{\circ} \mathrm{C}(\mathrm{CF}-$ 96 and CI 3-96) showed a higher $\mathrm{pH}$ than those with solutions at $67{ }^{\circ} \mathrm{C}$ (CF-67 and CI-67) at 25 days of fermentation, but the $\mathrm{pH}$ difference was not significant. 


\section{Current Trends in Natural Sciences}

Vol. 10, Issue 19, pp. 321-327, 2021

https://doi.org/10.47068/ctns.2021.v10i19.041

Current Trends in Natural Sciences (on-line)

Table 1. Synthesis of results on pH values during lactic fermentation

\begin{tabular}{|l|c|c|c|c|c|c|}
\hline \multirow{2}{*}{\multicolumn{1}{c|}{ Experimental variant }} & \multicolumn{7}{|c|}{ Time interval (days) } \\
\cline { 2 - 7 } & $\mathbf{0}$ & $\mathbf{5}$ & $\mathbf{1 0}$ & $\mathbf{1 5}$ & $\mathbf{2 0}$ & $\mathbf{2 5}$ \\
\hline $\mathrm{a}_{1} \mathrm{~b}_{0}$ - Blanching at $96{ }^{\circ} \mathrm{C}$ & 6.03 & 5.57 & 3.64 & 3.34 & 3.32 & 3.23 \\
\hline $\mathrm{a}_{1} \mathrm{~b}_{1}$ - Sea salt & 6.02 & 5.66 & 3.55 & 3.29 & 3.21 & 3.20 \\
\hline $\mathrm{a}_{1} \mathrm{~b}_{2}$ - Sliced sample (CF-96) & 6.01 & 5.83 & 3.70 & 3.65 & 3.56 & 3.43 \\
\hline $\mathrm{a}_{1} \mathrm{~b}_{3}$ - Unsliced sample (CI-96) & 5.59 & 5.78 & 3.85 & 3.77 & 3.56 & 3.55 \\
\hline $\mathrm{a}_{2} \mathrm{~b}_{0}$ - Blanching at 67 ${ }^{\circ} \mathrm{C}$ & 6.00 & 5.29 & 3.44 & 3.36 & 3.34 & 3.23 \\
\hline $\mathrm{a}_{2} \mathrm{~b}_{1}$ - Sea salt & 6.02 & 5.67 & 3.56 & 3.30 & 3.23 & 3.20 \\
\hline $\mathrm{a}_{2} \mathrm{~b}_{2}$ - Sliced sample (CF-67) & 6.01 & 5.28 & 3.52 & 3.55 & 3.39 & 3.37 \\
\hline $\mathrm{a}_{2} \mathrm{~b}_{3}$ - Unsliced sample (CI-67) & 6.01 & 5.35 & 3.70 & 3.51 & 3.48 & 3.40 \\
\hline
\end{tabular}
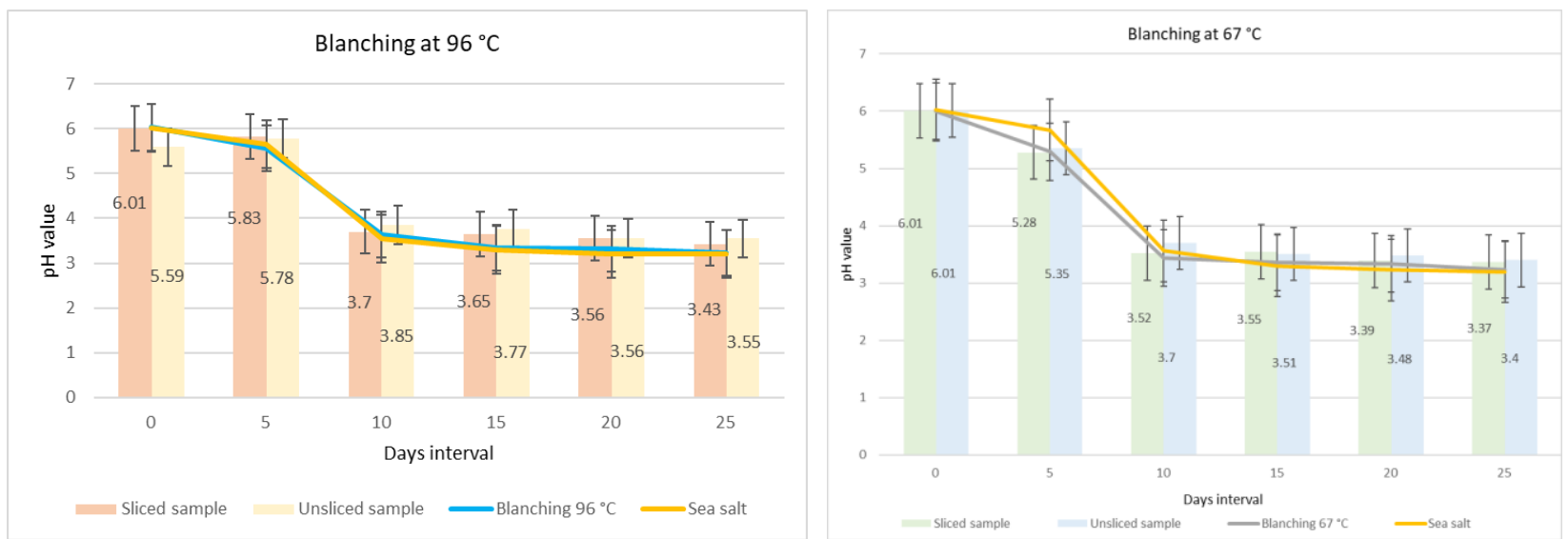

Figure 1. Graphical representation of recorded $\mathrm{pH}$ values during lactic fermentation

The summary of results on titratable acidity values are shown in Table 2, and changes according to the experimental variants analyzed are shown in Figure 2.

Table 2. Synthesis of results on titratable acidity during lactic fermentation

\begin{tabular}{|l|c|c|c|c|c|c|}
\hline \multirow{2}{*}{\multicolumn{1}{|c|}{ Experimental variant }} & \multicolumn{7}{c|}{ Time interval (days) } \\
\cline { 2 - 7 } & $\mathbf{0}$ & $\mathbf{5}$ & $\mathbf{0}$ & $\mathbf{1 5}$ & $\mathbf{0}$ & $\mathbf{2 5}$ \\
\hline $\mathrm{a}_{1} \mathrm{~b}_{0}$ - Blanching at $96{ }^{\circ} \mathrm{C}$ & 0.13 & 0.13 & 0.57 & 0.68 & 0.70 & 0.79 \\
\hline $\mathrm{a}_{1} \mathrm{~b}_{1}$ - Sea salt & 0.10 & 0.13 & 0.48 & 0.63 & 0.65 & 0.68 \\
\hline $\mathrm{a}_{1} \mathrm{~b}_{2}$ - Sliced sample $(\mathrm{CF}-96)$ & 0.12 & 0.12 & 0.55 & 0.69 & 0.70 & 0.76 \\
\hline $\mathrm{a}_{1} \mathrm{~b}_{3}$ - Unsliced sample (CI-96) & 0.14 & 0.14 & 0.59 & 0.75 & 0.78 & 0.79 \\
\hline $\mathrm{a}_{2} \mathrm{~b}_{0}$ - Blanching at $67{ }^{\circ} \mathrm{C}$ & 0.11 & 0.15 & 0.51 & 0.74 & 0.88 & 0.85 \\
\hline $\mathrm{a}_{2} \mathrm{~b}_{1}$ - Sea salt & 0.12 & 0.14 & 0.50 & 0.65 & 0.68 & 0.70 \\
\hline $\mathrm{a}_{2} \mathrm{~b}_{2}$ - Sliced sample (CF-67) & 0.10 & 0.14 & 0.52 & 0.73 & 0.84 & 0.82 \\
\hline $\mathrm{a}_{2} \mathrm{~b}_{3}$ - Unsliced sample (CI-67) & 0.12 & 0.13 & 0.58 & 0.68 & 0.85 & 0.80 \\
\hline
\end{tabular}




\section{Current Trends in Natural Sciences}

Vol. 10, Issue 19, pp. 321-327, 2021

https://doi.org/10.47068/ctns.2021.v10i19.041

Current Trends in Natural Sciences (on-line)
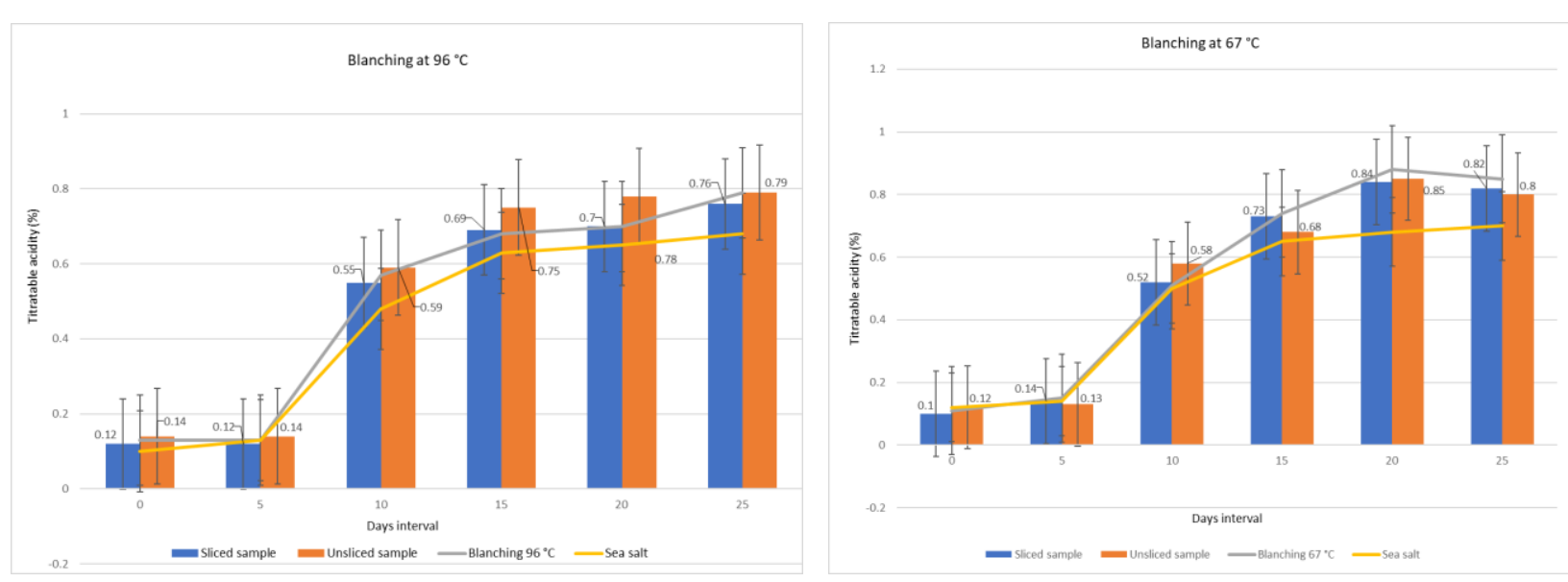

Figure 2. Graphical representation of recorded titratable acidity values during lactic fermentation

Titratable acidity increased with decreasing $\mathrm{pH}$, reached a high level after 10 days of lactic fermentation and not changed rapidly in the later stage of fermentation. In the CF samples in the salt solution blanched at $96{ }^{\circ} \mathrm{C}$, the final titratable acidity was lower than in the sea salt solution blanched at $67{ }^{\circ} \mathrm{C}$.

The average values of salt concentration are shown in Table 3, and the changes during lactic fermentation are shown in Figure 3.

Table 3. Synthesis of results on salt concentration during lactic fermentation

\begin{tabular}{|l|c|c|c|c|c|c|}
\hline \multirow{2}{*}{ Experimental variant } & \multicolumn{5}{c|}{ Time interval (days) } \\
\cline { 2 - 7 } & $\mathbf{0}$ & $\mathbf{5}$ & $\mathbf{0}$ & $\mathbf{1 5}$ & $\mathbf{0}$ & $\mathbf{2 5}$ \\
\hline $\mathrm{a}_{1} \mathrm{~b}_{0}$ - Blanching at $96^{\circ} \mathrm{C}$ & 0.00 & 4.51 & 4.72 & 4.73 & 4.77 & 4.80 \\
\hline $\mathrm{a}_{1} \mathrm{~b}_{1}$ - Sea salt & 0.00 & 4.34 & 4.61 & 4.64 & 4.67 & 4.70 \\
\hline $\mathrm{a}_{1} \mathrm{~b}_{2}$ - Sliced sample (CF-96) & 0.00 & 4.48 & 4.66 & 4.69 & 4.71 & 4.75 \\
\hline $\mathrm{a}_{1} \mathrm{~b}_{3}$ - Unsliced sample (CI-96) & 0.00 & 4.52 & 4.73 & 4.75 & 4.77 & 4.79 \\
\hline $\mathrm{a}_{2} \mathrm{~b}_{0}$ - Blanching at $67^{\circ} \mathrm{C}$ & 0.00 & 4.43 & 4.60 & 4.63 & 4.58 & 4.57 \\
\hline $\mathrm{a}_{2} \mathrm{~b}_{1}$ - Sea salt & 0.00 & 4.39 & 4.51 & 4.52 & 4.42 & 4.53 \\
\hline $\mathrm{a}_{2} \mathrm{~b}_{2}$ - Sliced sample (CF-67) & 0.00 & 4.47 & 4.57 & 4.57 & 4.56 & 4.56 \\
\hline $\mathrm{a}_{2} \mathrm{~b}_{3}$ - Unsliced sample (CI-67) & 0.00 & 4.50 & 4.70 & 4.70 & 4.62 & 4.65 \\
\hline
\end{tabular}

In fact, after 5 days of fermentation, the salt concentrations reached $4.34-4.51 \%$ and changed slowly until the 25th day, but there was no significant difference between the bleaching samples at different temperatures.

The salt seemed to penetrate the cucumbers faster at the initial stage of fermentation than at its later stage and sliced cucumbers. 


\section{Current Trends in Natural Sciences}

Vol. 10, Issue 19, pp. 321-327, 2021

https://doi.org/10.47068/ctns.2021.v10i19.041

Current Trends in Natural Sciences (on-line)
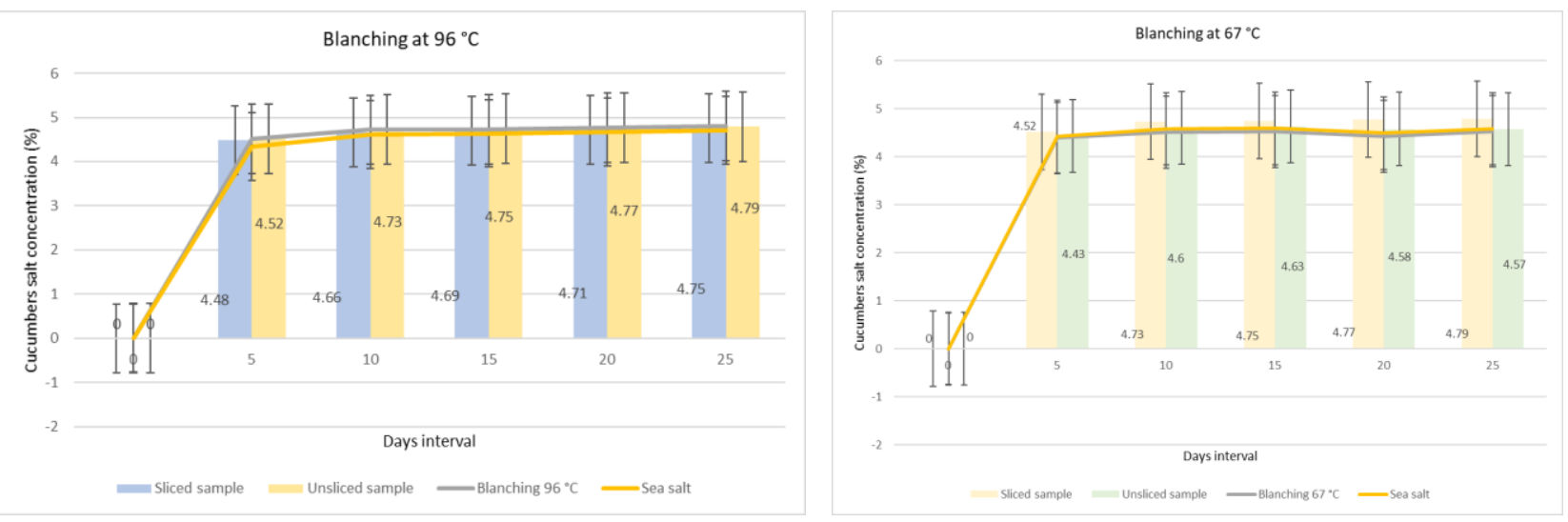

Figure 3. Graphical representation of recorded cucumbers salt concentrations values during lactic fermentation

This changes in the cucumbers salt concentrations appeared to be caused by higher osmotic pressure in the initial fermentation stage.

\section{CONCLUSIONS}

The results of this study show that iodized sea salt was useful for whole pickles because they showed a better taste and texture. Pickled cucumbers blanched at $96{ }^{\circ} \mathrm{C}$ showed a better texture and lower acidity than those at $67^{\circ} \mathrm{C}$.

Therefore, CI-96 is considered to be the best preheating condition for pickles given the texture, taste and ease of preparation.

\section{REFERENCES}

Adams, P., Graves, C.J., and Winsor, G.W. (1992). Some responses of cucumbers, grown in beds of peat to N, K and $\mathrm{Mg}$, Hort. Science 67, 877-84.

Alfredo, M., Antonio, H.S., Luis, R., Castro, A. (1997). Processing and storage of lyetreated carrots fermented by a mixed starter culture, Int J Food Microbiol 35, 83-90.

Ashaolu, T.J. (2019). A review on selection of fermentative microorganisms for functional foods and beverages: The production and future perspectives. Int. J. Food Sci. Technol., 54, 2511-2519.

Ashaolu, T.J. (2020). Safety and quality of bacterially fermented functional foods and beverages: A mini review. Food Quality and Safety, 4(3), 123-127.

de Roos, J., de Vuyst, L. (2018). Acetic acid bacteria in fermented foods and beverages. Curr. Opin. Biotechnol. 49, 115-119.

Fleming, H.P., McFeeters, R.F., Daeschel, M.A., Humphries, E.G., Thompson, R.L. (1988). Fermentation of cucumbers in anaerobic tanks, J Food Sci 53, 127-133.

Franco, W., Johanningsmeier, S.D., Lu, J., Demo, J., Wilson, E., Moeller, L. (2016). Fermentation of cucumbers; Cap. 7, pp, 107-155, CRC Press: Boca Raton, FL, SUA.

Hoza, G. (2013). Research regarding the influence of various pruning systems at Cornichon cucumber cultivated in solarium, Journal of Horticulture, Forestry and Biotechnology Timisoara, 17(1), 219- 222.

Ly, D., Mayrhofer, S., Domig, K. (2018), Significance of traditional fermented foods in the lower Mekong subregion: A focus on lactic acid bacteria. Food Biosci. 26, 113-125.

Mäki, M. (2004). Lactic Acid Bacteria in Vegetable Fermentations. Food Sci. Technol. N. Y. Marcel Dekker 139, 419430.

More, T.A. (2015). Cucurbitaceous Vegetables (Cucumber), Textbook of Vegetables, Tuber and Spice crops, 254-261.

Ray, R.C., Sivakumar, P.S. (2009). Traditional and novel fermented foods and beverages from tropical root and tuber crops. Int. J. Food Sci. Technol., 44, 1073-1087. 


\section{Current Trends in Natural Sciences}

Vol. 10, Issue 19, pp. 321-327, 2021

https://doi.org/10.47068/ctns.2021.v10i19.041

Current Trends in Natural Sciences (on-line)

Sanlier, N., Gökcen, B.B., Sezgin, A.C. (2017). Health benefits of fermented foods. Crit. Rev. Food Sci. Nutr. 59, 506527.

Simatende, P., Gadaga, T.H., Nkambule, S.J., Siwela, M. (2015). Methods of preparation of Swazi traditional fermented foods. J. Ethn. Foods. 2, 119-125.

Swain, M.R., Anandharaj, M., Ray, R.C., Rani, R.P. (2014). Fermented fruits and vegetables of asia: A potential source of probiotics. Biotechnol. Res. Int., 2014, 1-19.

Tamang, J., Thapa, N., Tamang, B., Rai, A. (2015). Health Benefits of Fermented Foods and Beverages; Microorganisms in fermented foods and beverages; pp. 1-110, CRC Press: Boca Raton, FL, USA.

Tamang, J.P., Sarkar, P.K. (1993) Sinki: a traditional lactic acid fermented radish tap root product. J. Gen. ppl. Microbiol., 39, 395-408. 